\title{
Risk Factors of First Febrile Seizures Admitted in a Tertiary Care Hospital
}

\author{
Fauzia Nahid ', Farhana Rahman ${ }^{2}$, Md. Mahbubul Hoque ${ }^{3}$, Md. Ruhul Amin ${ }^{3}$, Tahmina Yasmin ${ }^{4}$, Rawshan Ara ${ }^{5}$
}

\begin{abstract}
:
Background \& objective: Febrile seizure (FS) is the most common convulsive event in children. It is the most common type of seizure that every pediatrician has to deal with. However, the etiology of febrile seizure is still unclear. The present study was intended to identify the risk factors of first febrile convulsion among 6 months to 5 years old children.
\end{abstract}

Materials \& Methods: A case-control study was carried out on a total of 200 children-100 cases (children with febrile convulsion) \& 100 controls (without febrile convulsion) selected from the In-patient Department of Dhaka Shishu Hospital over a period of six months between May 2012 to October 2012. Data were collected on variables of interest using a semi-structured research instrument. The Chi-square test and Odd Ratio were employed to compare the risk factors between case and control groups.

Result: There was no association of febrile seizure with age of the children, but males were more often associated with FS than the females with risk of developing febrile seizures in boys was 3.5 -fold ( $95 \% \mathrm{CI}=1.8$ $-6.8)$ higher than that in girls $(p<0.001)$. The risk of having FS in children with prematurity and caesarean delivery was 2.8 times ( $95 \% \mathrm{CI}=1.5-5.0)$ and 2 -times ( $95 \% \mathrm{CI}=1.4-2.6)$ greater than those in children without having these conditions ( $p=0.001$ and $p<0.001$ respectively). The children with family history of febrile seizure tends to be associated with first febrile seizures and the odds of having the condition is 36.4 (95\% $\mathrm{CI}=15.4-85.7)$. There was no significant relationship between family history of epilepsy and first febrile seizure $(p=0.061)$. The children with shorter duration of breast feeding $(6-12$ months) carry $2.9(95 \% C I=2.0-4.0)$ times higher risk of having first febrile seizure than those with longer duration of breast-feeding $(p<0.001)$. Exclusively breast-fed children were less susceptible to develop febrile seizures (OR=0.149, 95\% CI: 0.08-0.23). Twelve cases developed perinatal asphyxia as opposed to only 2 of the control group and the risk of having FS in children with perinatal asphyxia was $1.8(95 \% \mathrm{CI}=1.4-2.3)$ times higher than those without having the history ofperinatal asphyxia $(p<0.001)$. Three-quarters of the children presented with FS had viral fever whereas only $4 \%$ of the controls had viral fever indicating that viral fever triggers the development of FS much more frequently than any other childhood illness $(p<0.001)$.

Conclusion: The study concluded that male sex, preterm baby, positive family history of febrile seizures, less than 6 months of exclusive breast feeding, not continuing the breast-feeding beyond 12 months, perinatal asphyxia and viral infections are the predictors of first febrile seizure. Preventive measures in removing these risk factors can go a long way to a decrease the incidence of febrile seizures.

Key words: Children, first febrile seizure, risk factors etc.

\section{Authors' information:}

${ }^{1}$ Dr. Fauzia Nahid, Assistant Professor (Pediatrics), Dhaka Central International Medical College \& Hospital (DCIMCH), Dhaka.

${ }_{2}^{2}$ Dr Farhana Rahman, Assistant Professor (Pediatrics), Delta Medical College, Dhaka.

${ }^{3}$ Md. Mahbubul Hoque, Professor (Neonatology), Dhaka Shishu Hospital, Dhaka.

${ }^{3}$ Dr. Md. Ruhul Amin, Assistant Professor, Pediatrics, Rangpur Medical College, Rangpur.

${ }^{4}$ Dr. Tahmina Yasmin, Assistant Register, IbnSina Medical College Hospital, Dhaka.

${ }^{5}$ Dr. Rawshan Ara, Assistant Register, Dhaka Central International Medical College \& Hospital (DCIMCH).

Correspondence: Dr.Fauzia Nahid, Phone:+88001716919571E-mail:kamal93517@gmail.com \& fauzianahid1980@gmail.com 


\section{Introduction:}

Febrile seizures are the most common seizures of childhood, occurring in 2 to 5 percent of children between six months to five years of age. ${ }^{1}$ It is defined by The International League Against Epilepsy (ILAE) as "a seizure occurring in childhood after one month of age, associated with a febrile illness not caused by an infection of the central nervous system, without previous neonatal seizures or a previous unprovoked seizure, and not meeting the criteria for other acute symptomatic seizures."2 As defined by the American Academy of Pediatrics (AAP), febrile seizures occur in the absence of intracranial infection, metabolic disturbance and are classified as simple or complex. ${ }^{1,3}$ Simple febrile seizures represent 65 to 90 percent of febrile seizures. ${ }^{3}$ A simple febrile seizureis defined as a generalized, self-limiting tonic-clonic seizure for a duration of $<15 \mathrm{~min}$ and does not usually recur within the next 24 hours, not have any previous neurologic problems and does not leave any postictal pathology. On the other hand, a complex FS is defined as having one or more of the following features: (i) a focal onset or focal features during the seizure, or a seizure followed by a neurological deficit (ii) prolonged duration (>15 $\mathrm{min}$ ), (iii) recurrent seizures within the same febrile illness over a 24-hour period (iv) previous neurological impairment, such as cerebral palsy or developmental delay. ${ }^{4}$

Several reports indicate that different factors including the environmental and genetic factors influence the occurrence of febrile seizure. ${ }^{5}$ Risk factors for febrile seizures include developmental delay, discharge from a neonatal unit after 28 days, day care attendance, viral infections, a family history of febrile seizure, certain vaccinations, \& possibly iron and zinc deficiencies. Febrile seizures may occur before or soon after the onset of fever, with the likelihood of seizure increasing with the child's temperature and not with the rate of temperature rise. ${ }^{6}$ A Cochrane review and a review of 530,000 children receiving the MMR vaccine showed that the risk of febrile seizures increased only during the first two weeks after vaccination and was likely to be related to fever resulting from the vaccine. ${ }^{7}$ A genetic predisposition for febrile seizures has been postulated, although no susceptible gene has been identified. ${ }^{8}$ Viral infections commonly trigger febrile seizures, particularly infection with primary human herpesvirus. ${ }^{7,9}$ Several studies have emphasized that prematurity and delivery complications could act as risk factors for occurrence of first febrile seizure. ${ }^{10}$ Children who have experienced a simple febrile seizure are at risk of declining IQ, epilepsy, recurrent febrile seizures and death. ${ }^{11-13}$

The vast majority of febrile seizures are of short duration and harmless. There is no evidence that short febrile seizures cause brain damage. Children with febrile seizures who face an increased risk of developing epilepsy include those who have cerebral palsy, delayed development, or other neurological abnormalities, or who have febrile seizures that are of longer duration or affect only one part of the body. ${ }^{14}$ Given the high prevalence of febrile seizures in children, efforts have to be made in identifying the risk factors associated with the occurrence of disease. Hence, the present study intended to investigate the risk factors of febrile seizures in children is of utmost significance, for knowing the risk factors of the $1^{\text {st }}$ febrile seizure has immense preventive implication.

\section{Materials \& Methods:}

This case-control study was conducted over a period of 6 months from May 2012 to October 2012 in the In-patient Department of Dhaka Shishu Hospital, Dhaka. Febrile children with or without convulsion admitted in different wards in Dhaka Shishu Hospital were the study population. A total of 66 children of both sexes, aged 06-60 months diagnosed as first attack of febrile seizure as per American Academy of Paediatrics criteria were consecutively included in the study. However, children diagnosed as intracranial infection based on CSF study and recurrent attacks of febrile seizures were excluded from the study.

The axillary temperature was recorded properly at admission followed by history taking and lumber puncture for CSF investigation. While children who 
met the eligibility criteria of first attack of febrile seizure and had no evidence of central nervous system infection (normal CSF findings) were enrolled in the case group, children who admitted with fever but without convulsion were selected as control group. The history of clinical manifestations that were observed in this study were exclusive breast feeding, breast feeding duration, viral infection, upper respiratory tract infection, UTI, gastroenteritis, family history of febrile seizure or epilepsy, birth history and pre-maturity. In both case and control groups investigations like $\mathrm{CBC}$ with peripheral blood film, urine for R/E, X-ray chest, blood for C/S were done to search the causes of fever. Length of hospital stay and outcome were also recorded. All patients received the usual treatment for febrile seizure. The data were analyzed using Statistical Package for Social Sciences (SPSS) for Windows, version 17.0. Quantitative variables were expressed as mean \pm SD and were compared between groups using Student's t-Test. Qualitative variables were expressed as the frequency distribution of each category with corresponding percentages and were compared between groups using Chi-square or Fisher's Exact Test. The Odds Ratio (OR) was estimated to find the risk of having febrile seizure in case group compared to that in control group. Level of significance was set at $5 \%$ and a P-value of $<0.05$ was considered statistically significant.

\section{Results:}

The mean age of the children with and without febrile seizure was $13.2 \pm 4.5$ months and $12.4 \pm$ 4.2 months respectively. More than half (52\%) of the children in case group and $56 \%$ in control group belonged to $12-24$ months age group. Of the 100 children with febrile seizures $84 \%$ were male and $16 \%$ were female, whereas in control group male and female were $60 \%$ and $40 \%$ respectively. Males were more often associated with FS than the females. The risk of developing febrile seizures in boys was 3.5-fold (95\% CI = 1.8 -6.8) higher than that in girls $(p<0.001$ ) (Table I). Over half the cases (52\%) was born preterm ( $<37$ weeks of gestation), whereas $28 \%$ of the control group children were preterm $(p<0.001)$.
The risk of having FS in children with history of prematurity was $2.8(95 \% \quad C I=1.5-5.0)$ times higher than that in children without FS. Nearly two-thirds $(64 \%)$ of the cases was born with cesarean section as opposed to one-third (32\%) of the controls $(p<0.001)$. The risk of developing FS in children with LUCS is nearly 2-times greater (95\% CI=1.4-2.6) than that in children without LUCS (Table II).

More than three-fourth (76\%) of the cases had a positive family history of febrile seizure, whereas large majority of the control group (92\%) did not have any link with family history of febrile seizure suggesting that children with family history of febrile seizure tends to be associated with first febrile seizures and the odds of having the condition is 36.4 ( $95 \% \mathrm{CI}=15.4-85.7)$. Four percent of cases had positive family history of epilepsy as compared to none of the controls. There was no significant relationship between family history epilepsy and first febrile seizure $(p=0.061)$ (Table III). The children with shorter duration of breast feeding ( $6-12$ months) was found to be associated with $2.9(95 \% \mathrm{CI}=2.0-$ 4.0) times higher risk of having first febrile seizure than those with longer duration of breast-feeding $(p<0.001)$. Only about a quarter of the cases (24\%) accomplished exclusive breast feeding for 6 months, although $68 \%$ of the controls were found to be exclusively breast-fed. Exclusively breast-fed children were less susceptible to develop febrile seizures (OR $=0.149,95 \%$ CI: $0.08-0.23$ ) (Table IV). Twelve cases developed perinatal asphyxia as opposed to only 2 of the control group and the risk of having FS in children with perinatal asphyxia was $1.8(95 \% \mathrm{CI}=1.4-2.3)$ times higher than those without having the history perinatal asphyxia ( $p<0.006)$ (Table V). Seventy five percent of the children presented with FS had viral fever whereas only $4 \%$ of the controls had viral fever. Gastroenteritis, pneumonia, urinary tract infection (UTI) and enteric fever in case group were $10,8,5$ and $2 \%$ cases respectively, which in the control group were $32,44,8$ and $12 \%$ respectively. Viral fever trigger the development of FS much more frequently than any other diseases presented in the table $(p<0.001)$ (Table VI). 


\begin{tabular}{|c|c|c|c|c|}
\hline \multicolumn{5}{|c|}{$\begin{array}{l}\text { TABLE I. Comparison of demographic characteristics of the } \\
\text { children between groups }\end{array}$} \\
\hline \multirow{2}{*}{$\begin{array}{l}\text { Demographic } \\
\text { characteristics }\end{array}$} & \multicolumn{2}{|c|}{ Group } & \multirow{2}{*}{$\begin{array}{l}\text { Odds Ratio } \\
(95 \% \mathrm{Cl})\end{array}$} & \multirow[b]{2}{*}{ p-value } \\
\hline & $\begin{array}{c}\text { Case } \\
(n=100)\end{array}$ & $\begin{array}{l}\text { Control } \\
(n=100)\end{array}$ & & \\
\hline \multicolumn{5}{|l|}{ Age (months) } \\
\hline $6-12$ & $44(44.0)$ & $44(44.0)$ & \multirow{3}{*}{---} & \multirow{3}{*}{0.932} \\
\hline $13-24$ & $52(52.0)$ & $56(56.0)$ & & \\
\hline $25-36$ & $4(4.0)$ & $0(0.0)$ & & \\
\hline \multicolumn{5}{|l|}{ Sex } \\
\hline Male & $84(84.0)$ & $60(60.0)$ & \multirow{2}{*}{$3.5(1.8-6.8)$} & \multirow{2}{*}{$<0.001$} \\
\hline Female & $16(16.0)$ & $40(40.0)$ & & \\
\hline
\end{tabular}

Figures in the parentheses denote corresponding percentage Data were analysed using Chi-squared $\left(\chi^{2}\right)$ Test; $\mathrm{OR}=$ Odds Ratio.

\begin{tabular}{|c|c|c|c|c|}
\hline \multirow{2}{*}{$\begin{array}{l}\text { Obstetric } \\
\text { characteristics }\end{array}$} & \multicolumn{2}{|c|}{ Group } & \multirow{2}{*}{$\begin{array}{l}\text { Odds Ratio } \\
\text { (95\% Cl for OR) }\end{array}$} & \multirow[b]{2}{*}{ p-value } \\
\hline & $\begin{array}{c}\text { Case } \\
(n=100)\end{array}$ & $\begin{array}{l}\text { Control } \\
(n=100)\end{array}$ & & \\
\hline \multicolumn{3}{|c|}{ Gestational age (weeks) } & \multirow{3}{*}{$2.8(1.5-5.0)$} & \multirow{3}{*}{0.001} \\
\hline$<37$ (Preterm) & $52(52.0)$ & $28(28.0)$ & & \\
\hline$\geq 37$ (Term) & $48(48.0)$ & $72(72.0)$ & & \\
\hline \multicolumn{3}{|l|}{ Mode of delivery } & & \\
\hline LUCS & $64(64.0)$ & $32(32.0)$ & \multirow{2}{*}{$1.9(1.4-2.6)$} & \multirow{2}{*}{$<0.001$} \\
\hline NVD & $36(36.0)$ & $68(68.0)$ & & \\
\hline
\end{tabular}

Figures in the parentheses denote corresponding percentage Data were analysed using Chi-squared $\left(\chi^{2}\right)$ Test; $\mathrm{OR}=$ Odds Ratio.

\begin{tabular}{|c|c|c|c|c|}
\hline \multicolumn{5}{|c|}{$\begin{array}{l}\text { TABLE III. Association between first FS and family history of } \\
\text { FS/epilepsy }\end{array}$} \\
\hline \multirow{2}{*}{$\begin{array}{l}\text { Family history } \\
\text { of FS/epilepsy }\end{array}$} & \multicolumn{2}{|c|}{ Group } & \multirow{2}{*}{$\begin{array}{l}\text { Odds Ratio } \\
\text { (95\% Cl for OR) }\end{array}$} & \multirow[b]{2}{*}{$\mathrm{p}$-value } \\
\hline & $\begin{array}{c}\text { Case } \\
(\mathrm{n}=100)\end{array}$ & $\begin{array}{l}\text { Control } \\
(n=100)\end{array}$ & & \\
\hline \multicolumn{5}{|c|}{ Family history of epilepsy } \\
\hline Yes & $76(76.0)$ & $8(8.0)$ & $36.4(95 \% \mathrm{Cl}=15.4-85.7)$ & $<0.001$ \\
\hline No & $24(24.0)$ & $92(92.0)$ & & \\
\hline \multicolumn{5}{|c|}{ Family history of FS } \\
\hline LUCS & $4(4.0)$ & $0(0.0)$ & No computable & 0.061 \\
\hline NVD & $96(36.0)$ & $100(100.0)$ & & \\
\hline
\end{tabular}

Figures in the parentheses denote corresponding percentage Data were analysed using Chi-squared $\left(\chi^{2}\right)$ Test; $\mathrm{OR}=$ Odds Ratio.

\section{TABLE IV. Association between FS and breast feeding}

\begin{tabular}{|c|c|c|c|c|}
\hline \multirow{2}{*}{$\begin{array}{l}\text { Obstetric } \\
\text { characteristics }\end{array}$} & \multicolumn{2}{|c|}{ Group } & \multirow{2}{*}{$\begin{array}{l}\text { Odds Ratio } \\
\text { ( } 95 \% \text { Cl for OR) }\end{array}$} & \multirow[b]{2}{*}{ p-value } \\
\hline & $\begin{array}{c}\text { Case } \\
(n=100)\end{array}$ & $\begin{array}{l}\text { Control } \\
(n=100)\end{array}$ & & \\
\hline \multicolumn{5}{|c|}{ Duration of breast feeding (months) } \\
\hline $6-12$ & $76(76.0)$ & $28(28.0)$ & \multirow{2}{*}{$2.9(2.0-4.0)$} & \multirow{2}{*}{$<0.001$} \\
\hline$>12-24$ & $24(24.0)$ & $72(72.0)$ & & \\
\hline \multicolumn{5}{|c|}{ Exclusive breast feeding } \\
\hline 6 months & $24(24.0)$ & $68(68.0)$ & \multirow{2}{*}{$0.149(0.080-0.227)$} & \multirow{2}{*}{$<0.001$} \\
\hline$<6$ months & $76(36.0)$ & $32(32.0)$ & & \\
\hline
\end{tabular}

Figures in the parentheses denote corresponding percentage Data were analysed using Chi-squared $\left(\chi^{2}\right)$ Test; $\mathrm{OR}=$ Odds Ratio.

TABLE V. Association between perinatal asphyxia and febrile seizure in children

\begin{tabular}{|c|c|c|c|c|}
\hline \multirow{2}{*}{$\begin{array}{l}\text { Perinatal } \\
\text { asphyxia }\end{array}$} & \multicolumn{2}{|c|}{ Group } & \multirow{2}{*}{$\begin{array}{l}\text { Odds Ratio } \\
(95 \% \mathrm{Cl})\end{array}$} & \multirow[b]{2}{*}{ p-value } \\
\hline & $\begin{array}{c}\text { Case } \\
(n=100)\end{array}$ & $\begin{array}{l}\text { Control } \\
(n=100)\end{array}$ & & \\
\hline Yes & $12(12.0)$ & $2(2.0)$ & \multirow{2}{*}{$1.8(1.4-2.3)$} & \multirow{2}{*}{0.006} \\
\hline No & $88(88.0)$ & 98(98.0) & & \\
\hline
\end{tabular}

Figures in the parentheses denote corresponding percentage Data were analysed using Chi-squared $\left(\chi^{2}\right)$ Test; OR = Odds Ratio.

\begin{tabular}{|c|c|c|c|}
\hline \multirow{2}{*}{ Temperature } & \multicolumn{2}{|c|}{ Group } & \multirow{2}{*}{$\mathrm{p}$-value } \\
\hline & Case $(n=100)$ & Control $(n=100)$ & \\
\hline Viral fever & $75(75.0)$ & $4(4.0)$ & \multirow{5}{*}{$p<0.001$} \\
\hline Gastro-enteritis & $10(10.0)$ & $32(32.0)$ & \\
\hline Pneumonia & $8(8.0)$ & $44(44.0)$ & \\
\hline Enteric fever & $2(2.0)$ & $12(12.0)$ & \\
\hline UTI & $5(5.0)$ & $8(8.0)$ & \\
\hline
\end{tabular}

\section{Discussion:}

The exact cause of febrile seizure is unknown, however, there are several factors considered as risk factors associated with incidence of the first febrile seizures. In the present study age was not found to be associated with FS; however, more than half of the cases of first febrile seizure occurred in the second year of life which is in agreement with the results of AL-Zwaini et al. ${ }^{15}$ Sex was found to be associated with FS with boys being 3.5 times more at risk of having febrile seizure than the girls which is consistent with the findings of $\mathrm{Pal}$ et al. ${ }^{16}$ although there is no satisfactory explanation for this sex predominance. ${ }^{17}$ 
Risk for febrile seizure is associated with primary human herpes virus 6 infection, ${ }^{9}$ which is typically acquired during the first two years of life. In a case-control study, polymerase chain reaction testing and antibody titers suggested that 10 of 55 children (18 percent) who experienced a first febrile seizure had acute herpes virus 6 infection, whereas none of the 85 children with fever but no seizure had evidence of such infection. ${ }^{9}$

Children born preterm tend to be associated FS and the risk of having FS in children with prematurity was nearly three times higher than that in children without FS. AL-Zwaini and colleagues showed prematurity as a risk factor for febrile seizure. In a community-based case control study from Sweden, premature birth and bilirubinemia greater than $200 \mathrm{mmol} / \mathrm{L}$ were more common in febrile seizure. ${ }^{15}$ Ellatiff reported that the upper respiratory infections, family history of febrile seizure, prematurity, and labor difficulties were the major risk factors of the first febrile seizures. ${ }^{18}$ The present study demonstrated that children born with caesarean delivery tend to be associated FS and the risk of developing the condition in children with LUCS is nearly 2-times greater than that in children without LUCS.

Family history of febrile seizure in the current study was found to be a strong risk factor for first febrile seizures with the odds of having the condition is $36.4(95 \% \mathrm{CI}=15.4-85.7)$. This finding is in agreement with several other studies. ${ }^{16,18}$ The existence of family history of febrile seizure or epilepsy increases the risk of recurrent first febrile seizure. ${ }^{19}$ Febrile seizure and epilepsy in parents or siblings are usually associated with complex febrile seizure suggesting a genetic origin of complex febrile seizure. ${ }^{15}$

It was shown in a study that the mean breast-feeding duration in children with their first febrile seizures was significantly lower than those of healthy children. ${ }^{19}$ Consistent with this study our study showed that most of the children with FS had a breast feeding duration for 6-12 months which carries 1.78 times higher risk of having FS than those continued breast feeding up to 24 months. Additionally children who were exclusively breast-fed for first 6 months were $15 \%$ less prone to develop FS. Perinatal asphyxia contributed to the development of first febrile seizure in the present study. In another study ${ }^{20}$ perinatal asphyxia was considered an important risk factor for febrile seizures. Most of the cases in the present study presented with viral infections $(75.0 \%)$ followed by gastroenteritis $(10.0 \%)$, pneumonia $(8.0 \%)$, urinary tract infection $(5.0 \%)$, and enteric fever $(2.0 \%)$. In other study from Japan, approximately $90 \%$ of children with febrile seizures had upper and lower respiratory tract infection and exanthema subitum, and $20 \%$ of them was due to HHV-6 infection. Authors of the study concluded that Human Herpesvirus 6 (HHV-6) infection should be considered when children under $<1$ year age presents with a first FS. ${ }^{21}$

Summarizing the findings of the study and those of other studies compared and contrasted it is evident that sex, prematurity, family history of febrile seizures, duration of breast-feeding and exclusive breast feeding, perinatal asphyxia and viral infection were the risk factors for the first febrile seizures in children. Most of these factors was also found to be the predictors of first febrile seizures.

\section{Conclusion:}

Based on the findings, the study concluded that male sex, preterm baby, positive family history of febrile seizures, less than 6 months of exclusive breast feeding, not continuing the breast-feeding beyond 12 months, perinatal asphyxia and viral infections trigger the development of first febrile seizure. Preventive measures in removing these risk factors could lead to a decrease in incidence of febrile seizures. A child with febrile seizure usually doesn't need to be hospitalized. But if the seizure is prolonged or is accompanied by a serious infection, or if the source of the infection cannot be traced, the child should be hospitalized for observation. Prolonged daily use of oral anticonvulsants, such as phenobarbital or valproate, to prevent febrile seizure is usually not recommended because of their potential for side effects and questionable effectiveness for preventing such seizures. 


\section{References:}

1. American Academy of Pediatrics Steering Committee on Quality Improvement and Management, Subcommittee on Febrile Seizures. Febrile seizures: clinical practice guideline for the long-term management of the child with simple febrile seizures. Pediatrics 2008;121(6) :1281-86.

2. ILAE. Guidelines for epidemiologic studies on epilepsy. Epilepsia 1993;34(4):592-96.

3. Waruiru C \& Appleton R. Febrile seizures: an update. Arch Dis Child 2004;89(8):751-56.

4. Karande S. Febrile seizures: a review for family physicians. Indian J Med Sci 2007;61(3):161-72.

5. Mahyar A, Ayazi P, Fallahi M\&Javadi A. Risk factors of the first febrile seizures in Iranian children. Int J Pediatr 2010;78(5):141-43.

6. Berg AT, Shinnar S, Shapiro ED, Salomon ME, Crain EF 7 Hauser WA. Risk factors for a first febrile seizure: a matched case-control study. Epilepsia 1995;36(4): 334-1.

7. Demicheli V, Jefferson T, Rivetti A \& Price D. Vaccines for measles, mumps and rubella in children. Cochrane Database Syst Rev 2005;(4):CD004407.

8. Nakayama J. Progress in searching for the febrile seizure susceptibility genes. Brain Dev 2009;31(5): 359-65.

9. Laina I, Syriopoulou VP, Daikos GL, Roma ES, Papaqeorqiou F, Kakourou T et al. Febrile seizures and primary human herpesvirus 6 infection. Pediatr Neuro 2010;42 (1):28-31.

10. Vestergaard M, Wisborg K, Henriksen TB, Secher NJ, Ostergaard JR\& Olsen J. Prenatal exposure to cigarettes, alcohol, and coffee and the risk for febrile seizures. Pediatrics 2005;116(5):1089-94.

11. Chang YC, Guo NW, Huang CC, Wang ST \& Tsai JJ. Neurocognitive attention and behavior outcome of school age children with a history of febrile convulsions: a population study. Epilepsia 2000;41 (4):41220.
12. Nelson KB \&Ellenberg JH. Predictors of epilepsy in children who have experienced febrile seizures. $N$ Engl J Med 1976;295 (19):1029-33.

13. Annegers JF, Hauser WA, Shirts SB \& Kurland LT. Factors prognostic of unprovoked seizures after febrile convulsions. N Engl J Med 1987;316(9):493-98.

14. Febrile Seizures: Clinical Practice Guideline for the Long-term Management of the Child with Simple Febrile Seizures. Steering Committee on Quality Improvement and Management, Subcommittee on Febrile Seizures. Pediatrics 2008;121(6):1281-86.

15. AL-Zwaini EJ, AL-Ani SS, AL-Khalidi MJ \& AL-Taie MF. Risk Factors for Febrile Seizures: A Matched Case Control Study. IPMJ 2006;5(3):353-58.

16. Pal DK \& Kugler SL. Mandelbaum DE. Phenotypic features of familial febrile seizures: case control study. Neurology 2003;60:410-14.

17. Berg AT, Shinnar S, Darefsky AS, Holford TR, Shapiro E $D$, Salomon ME, et al.Predictors of recurrent febrile seizures. A prospective cohort study. Arch Pediatr Adolesc Med 1997;151(4):371-8.

18. Ellatiff \& H Garawamy. Risk factors of febrile disease among preschool children in Alexandria. J Egypt Public Health Associ 2002;77(1-2):159-72.

19. Mahyar A, Ayazi P, Fallahi M \&Javadi A. Risk Factors of the First Febrile Seizures in Iranian Children. International Journal of Pediatrics 2010;2010:Article ID 862897. http://dx.doi.org/10.1155/2010/862897

20. Abuekteish F, Daoud A. S, Al-Sheyyab M \& Nou'man M. Demographic characteristics and risk factors of first febrile seizures: a Jordanian experience. Trop Doct $2000 ; 30(1): 25-27$.

21. Suga S, Suzuki K, Ihira M, Yoshikawa T, kajita Y, Ozaki $\mathrm{T}$, et al. Clinical characteristics of febrile convulsion during primary HHV-6 infection. Arch Dis Chil 2000; 82:62-6. 